\title{
Crystallization Behavior during Melt-Processing of Ceramic Waste forms
}

\author{
Priyatham Tumurugoti ${ }^{a}$, S. K. Sundaram ${ }^{a}$, Scott T. Misture ${ }^{a}$ \\ James C. Marra ${ }^{\mathrm{b}}$, and Jake Amoroso, ${ }^{\mathrm{b}, *}$ \\ ${ }^{a}$ Kazuo Inamori School of Engineering, Then New York State College of Ceramics, \\ Alfred University, Alfred, NY 14802, USA \\ ${ }^{\mathrm{b}}$ Savannah River National Laboratory, Aiken, SC 29808, USA
}

\begin{abstract}
Multiphase ceramic waste forms based on natural mineral analogs are of great interest for their high chemical durability, radiation resistance, and thermodynamic stability. Melt-processed ceramic waste forms that leverage existing melter technologies will broaden the available disposal options for high-level nuclear waste. This work reports on the crystallization behavior in selected melt-processed ceramics for waste immobilization. The phase assemblage and evolution of hollandite, zirconolite, pyrochlore, and perovskite type structures during melt processing were studied using thermal analysis, x-ray diffraction, and electron microscopy. Samples prepared by melting followed by annealing and quenching were analyzed to determine and measure the progression of the phase assemblage. Samples were melted at $1500^{\circ} \mathrm{C}$ and heattreated at crystallization temperatures of $1285^{\circ} \mathrm{C}$ and $1325^{\circ} \mathrm{C}$ corresponding to exothermic events identified from differential scanning calorimetry measurements. Results indicate that the selected multiphase composition partially melts at $1500^{\circ} \mathrm{C}$ with hollandite coexisting as crystalline phase. Perovskite and zirconolite phases crystallized from the residual melt at temperatures below $1350^{\circ} \mathrm{C}$. Depending on their respective thermal histories, different quenched
\end{abstract}


samples were found to have different phase assemblages including phases such as perovskite, zirconolite and $\mathrm{TiO}_{2}$.

Keywords: waste form; crystallization; DSC; XRD, melt processing

[*] Corresponding Author: (Tel.) 803-819-4727; (E-mail): jake.amoroso@srs.gov

\subsection{Introduction}

Multiphase ceramic materials are of interest as an alternative to conventional borosilicate glass nuclear waste forms. Designing waste forms with the desired properties, including chemical corrosion resistance, radiation resistance, thermodynamic stability, and maximized waste loading, has been challenging [1]. Reprocessing used nuclear fuel (UNF) results in high-level waste (HLW) containing non-radioactive and radioactive elements that pose a long-term threat to the biosphere [2]. The idea of developing a suitable waste form for the various elements in a UNF HLW stream based on mineralogy is substantiated by the long-term durability of existing natural minerals $[3,4]$.

Synroc, a titanate based multiphase material, has been proposed $[5,6]$ to immobilize elements from nuclear waste streams. Synroc-C, a variant of Synroc formulation with hollandite, perovskite, zirconolite, and pyrochlore as major phases, is being developed for immobilizing HLW. Hollandite, with the general formula, $\left[\mathrm{Ba}_{x} \mathrm{Cs}_{y}\right]\left[\mathrm{M}^{3+}{ }_{2 x+y} \mathrm{Ti}_{8-2 x-y}\right] \mathrm{O}_{16}$ [7], is the primary host for Cs. The structure consists of a continuous network of edge and corner shared oxygen octahedra forming large tunnels running parallel to the c-axis $[8,9] . \mathrm{Ti}^{4+}$ and $\mathrm{M}^{3+}$ reside in the oxygen octahedral while the heavier ions $\mathrm{Ba}^{2+}$ and $\mathrm{Cs}^{+}$occupy the tunnel sites. Partial substitution of $\mathrm{Ti}^{4+}$ with trivalent cations $\mathrm{M}^{3+}$ or $\mathrm{Ti}^{3+}$ distorts the tunnel structure and facilitates the incorporation of larger Cs ions [10]. Perovskite $\left(\mathrm{CaTiO}_{3}\right)$ predominantly hosts alkaline earth or rare-earth elements (REEs) as $\mathrm{Ca}^{2+}$ or $\mathrm{Ti}^{4+}$ can be easily substituted by REEs. Wide ranges of 
cation combinations are possible that preserve the perovskite structure (e.g. $\mathrm{A}^{2+} \mathrm{B}^{4+} \mathrm{O}_{3}, \mathrm{~A}^{3+} \mathrm{B}^{3+} \mathrm{O}_{3}$ and $\left.\mathrm{A}^{1+} \mathrm{B}^{5+} \mathrm{O}_{3}\right)$ [11]. Zirconolite $\left(\mathrm{CaZrTi}_{2} \mathrm{O}_{7}\right)$ or pyrochlore, with the general formula $\mathrm{A}_{2} \mathrm{~B}_{2} \mathrm{O}_{7}$ $\left(\mathrm{A}^{3+} / \mathrm{B}^{4+}\right.$ or $\left.\mathrm{A}^{2+} / \mathrm{B}^{5+}\right)$, is the preferred host for $\mathrm{Zr}$ and minor actinides [12]. Various processes including conventional sintering [13], hot isostatic pressing (HIP) [14], cold crucible induction melting (CCIM) [15], and spark plasma sintering [16] have been used to prepare these ceramic waste forms.

The present study supports ongoing work to develop melt-processing as a viable method to produce durable ceramic waste forms. The compositional dependencies of processing temperature and crystallization phenomena present challenges to melting and solidification of multiphase, multicomponent ceramic waste forms. The resultant microstructures and phase assemblage depend on several parameters such as composition, interaction between different components in liquid and solid states, mobilities and diffusivities of different constituents, crucible dimensions, heat transfer, etc. However, limited literature is available on the crystallization behavior in melt-processed ceramic waste form materials.

In this work, thermal analysis and quench studies were performed to better understand nucleation and crystallization sequences of phases during melt-processing of multiphase waste forms. The present findings provide insight and understanding of the crystallization phenomenon and its impact on microstructure evolution during melt-processing. 


\subsection{Experimental}

\subsection{Waste form composition and preparation}

Savannah River National Laboratory (SRNL) developed the multiphase waste form composition [17-19] and provided batch materials for the experiments. The multiphase composition is based on simulated waste stream compositions that are currently being investigated under the DOE Fuel Cycle Research and Development (FCR\&D) program. Stoichiometric amounts of reagentgrade oxides and carbonates were blended together, mixed in de-ionized water with zirconia media, and dried at $90^{\circ} \mathrm{C}$. The resulting material was used as feed stock for experiments. The target composition, designated CAF-MP, is listed in Table 1. Bulk melt-processing was performed by heating the feed material in an alumina crucible or Pt foil to $1500^{\circ} \mathrm{C}$ at a rate of 5 $\mathrm{K} / \mathrm{min}$. Samples were typically held at $1500^{\circ} \mathrm{C}$ for $20 \mathrm{~min}$ and cooled to room temperature at 5 $\mathrm{K} / \mathrm{min}$.

\subsection{Viscosity measurements}

Viscosity, as a function of temperature, was measured in accordance with the American International C965 Procedure A [20] in which the viscosity was measured using a rotating spindle and a fixed crucible (both constructed of Pt-20\%Rh alloy). A portion of melt-processed (see Section 2.1) material was placed in the crucible and heated in a high temperature furnace. The temperature was initially set to achieve a condition (i.e. a melt or liquid-solid solution) in which the spindle could be lowered into the crucible. After steady-state conditions were obtained, the torque required to rotate the spindle at a constant speed was recorded with a Brookfield viscometer (Brookfield DV-II+, Brookfield Engineering Laboratories, USA). The temperature was then decreased incrementally and a series of such torque measurements at 
various temperatures was recorded until the viscosity increased beyond the instrument capability. Subsequently, a duplicate measurement was taken near the initial temperature to confirm the reversibility of the viscosity behavior. Experimentally derived instrument constants developed specifically for the SRNL system and verified with reference standards were used to calculate viscosity as a function of temperature from the recorded torque values [21, 22].

\subsection{Crystallization experiments}

Differential scanning calorimetry (DSC) was used to investigate crystallization as a function of temperature. A SETSYS Evolution DSC instrument (SETARAM Inc., Hillsborough, NJ, USA) was used to measure the heat flow from the material during heating and cooling. Figure 1 summarizes the DSC heating and cooling cycles. The maximum temperature for DSC measurements was $1500^{\circ} \mathrm{C}$, which was the melt-processing temperature used in this study. Heat cycles were chosen so that phase transformation behavior of CAF-MP, starting from unreacted stoichiometric mixture and as-formed compound, could be compared. A sample of $10-20 \mathrm{mg}$ of starting material was heated under helium atmosphere in Pt crucibles. Two heating rates, 20 and $5 \mathrm{~K} / \mathrm{min}$, were used for this study.

Quenching experiments were performed to investigate endothermic and exothermic events identified in the DSC data. Approximately, $4-5 \mathrm{~g}$ of starting material was wrapped in a custom folded Pt foil and pinch sealed. This samples were heated to $1500^{\circ} \mathrm{C}\left(\mathrm{T}_{\mathrm{m}}\right)$, held for 20 min, cooled to temperature ' $T$ ', equilibrated for time ' $t_{e q}$ ', and quenched in water by immersion. Temperature ' $T$ ' corresponded to exothermic peaks identified in DSC data. Figure 2 summarizes the time-temperature cycles used for these experiments. 


\subsection{Phase analysis}

Quenched samples were crushed and characterized using x-ray diffraction (XRD) for phase identification (D2 Phaser, Bruker AXS, USA). Diffraction patterns were collected from powder samples over $10-70^{\circ} 2 \theta$, at a rate of $0.02^{\circ}$ per second. Relative amounts of different phases

were determined by quantitative analysis. For quantitative phase analysis, the TOPAS 4.2 (Bruker AXS, Karlsruhe, Germany) software package was used. Relative amounts of phases were determined by generating calculated XRD patterns using Rietveld quantitative phase analysis together with the PDF-4+ (2013) structural database for crystallographic information. To get the best-fit to the experimental pattern, appropriate Crystallographic Information Files (CIF) were taken from PDF-4+ database and Rietveld structural refinement of different corresponding phases was performed.

Quenched samples were also characterized using electron microscopy to complement the XRD results. Composition and phase assemblage was investigated using scanning electron microscopy (SEM) (FEI Quanta 200F, USA) equipped with a field emission gun. In general, multiphase areas from each sample were selected from back-scattered electron (BSE) images and elemental maps were collected using JEOL JXA-8200, WD/ED Combined Electron Probe Microanalyzer (EPMA) (JEOL Ltd., Tokyo, Japan). Elemental scans over the selected area were performed at an accelerating potential of $15 \mathrm{kV}$, step size of $0.5 \mu \mathrm{m}$ in $x$ - and $y$-directions, and a dwell time of 80 milliseconds at each point.

\subsection{In-situ High-Temperature XRD studies}

In-situ melting and solidification behavior of CAF-MP was studied using high-temperature XRD (HTXRD) measurements. In-situ HTXRD was carried out using a diffractometer (Siemens $\theta-\theta$ D5000) equipped with a custom built high-temperature furnace using Co $K \alpha$ 
radiation. For the measurements, a thin, uniform layer of pre-reacted CAF-MP powder on a flat Pt disc was heated to $1500^{\circ} \mathrm{C}$ and cooled to room temperature. Diffraction patterns were collected at periodic isothermal temperature steps during the heating and cooling cycles, in the scan range $20-60^{\circ} 2 \theta$, with step size $0.037^{\circ}$ and a dwell time of $1 \mathrm{~s}$ at each step.

\subsection{Results and Discussion}

\subsection{Viscosity measurements}

The behavior of the viscometer during the measurements was not consistent with a homogenous Newtonian liquid. The torque values increased and decreased sporadically and were accompanied by visible locking and slipping of the viscometer spindle. This effect was accentuated at lower temperatures. This is indicative of a crystal phase coexisting in equilibrium with the melt at high temperatures. The effect of crystallization on the measured viscosity is difficult to predict but, it is not equal to the true viscosity of the melt and depends on the crystallization process and the stoichiometry of the crystals [23]. However, once crystals impinge, the apparent viscosity will increase due to blocking or interlocking effects of these crystals and eventually, flow will cease as the sample becomes fully crystalline. Indeed, this type of behavior was observed and although the nature of the melt-crystal composition is unknown, the viscosity behavior appeared reversible in the time span of the measurement as evidenced by the data taken upon re-heating. Figure 3 shows viscosity (in Poise) versus 1/ temperature (in $\mathrm{K}$ ) for the CAF-MP composition. The plot shows a rapid increase in viscosity as a function of temperature at approximately $1480^{\circ} \mathrm{C}$. It is unknown at what temperature the system is a complete melt because the liquidus temperature of the system was not determined. 


\subsection{DSC measurements and quenching experiments}

Figure 4 shows DSC curves corresponding to $20 \mathrm{~K} / \mathrm{min}$ and $5 \mathrm{~K} / \mathrm{min}$ heating/cooling rates. Exothermic peaks between 1280 and $1330^{\circ} \mathrm{C}$ were consistently observed during cooling of raw material and pre-reacted material from the melt temperature. At higher cooling rates, a single broad peak was observed, as might be expected in case of rapidly cooled samples in which the DSC signal from individual phase evolution events was convoluted into a single event. The DSC results provide supporting evidence for the coexistence of crystalline phases with a melt in this system.

Quenching experiments were designed based on the exothermic peak temperatures from the DSC curves, believed to be related crystallization events. Varying heat treatment times $\left(\mathrm{t}_{\mathrm{eq}}\right)$ were investigated to qualitatively understand phase evolution kinetics qualitatively. A baseline sample for comparison was heated to $1500^{\circ} \mathrm{C}$, held for $4 \mathrm{~h}$, and quenched. Table 2 summarizes the temperatures ' $T$ ' and corresponding dwell times ' $t_{e q}$ ' used for quenching experiments.

\subsection{Phase analysis and microstructural characterization}

All quenched samples, after heat treatment, were found to wet the Pt foil, indicating that melting occurred during their respective thermal histories. The baseline sample quenched from $1500^{\circ} \mathrm{C}$ was fully crystalline, as confirmed by $\mathrm{XRD}$. Figure 5 a compares the baseline measured XRD pattern to a calculated pattern using Rietveld quantitative phase analyses based on the following phases: $\mathrm{TiO}_{2}$ (PDF: 04-006-3570), hollandite (PDF: 04-013-6380), and tazheranite (PDF: 04-008-0260). During XRD phase analyses, it was observed that many phases in the CaO$\mathrm{ZrO}_{2}-\mathrm{TiO}_{2}$ system were close but not exact matches to the measured XRD patterns. Tazheranite $\left((\mathrm{Ca}, \mathrm{Zr}, \mathrm{Ti}) \mathrm{O}_{2}\right)$ is a naturally occurring cubic $\mathrm{ZrO}_{2}$ where $\mathrm{Zr}^{4+}$ is partially substituted by $\mathrm{Ca}^{2+}$ and $\mathrm{Ti}^{4+}$ ions $[24,25]$. Pure $\mathrm{ZrO}_{2}$, naturally occurring as baddeleyite, has monoclinic symmetry but 
transforms to tetragonal symmetry at $1170^{\circ} \mathrm{C}$ and to cubic symmetry at $2370^{\circ} \mathrm{C}$ [25]. Cubic $\mathrm{ZrO}_{2}$ with a fluorite-type structure can be stabilized at lower temperatures by the addition of tetravalent cations [26], trivalent rare-earth oxides, or divalent cations like $\mathrm{Ca}^{2+}[27]$. In addition to these, a number of other phases with similar structural motifs - calzirtite $\left(\mathrm{Ca}_{2} \mathrm{Zr}_{5} \mathrm{Ti}_{2} \mathrm{O}_{16}\right)$, zirconolite $\left(\mathrm{CaZrTi}_{2} \mathrm{O}_{7}\right)$, perovskite $\left(\mathrm{CaTiO}_{3} / \mathrm{CaZrO}_{3}\right)$ - that are stable at temperatures greater than $1200^{\circ} \mathrm{C}$ have been reported $[28,29]$. It can be understood that precise identification of zirconolite or related structures would become challenging during crystallization of multiphase melts given that a wide range of elements can form solid solutions with different phases in the $\mathrm{CaO}-\mathrm{ZrO}_{2}-\mathrm{TiO}_{2}$ system. Therefore, the chemistry of each phase in the X-ray Rietveld analysis were defined where possible using the elemental analysis from microscopy. The peaks indexed as tazheranite (Figure 5a) could correspond to several phase(s) in the $\mathrm{CaO}$ $\mathrm{ZrO}_{2}-\mathrm{TiO}_{2}$ system and hereafter referred to as $\mathrm{Ca}-\mathrm{Zr}-\mathrm{Ti}-\mathrm{O}$ phase.

A representative microstructure of the sample quenched from $1500^{\circ} \mathrm{C}$ is shown in Figure $5 \mathrm{~b}$. In that image, the darkest gray phase corresponds to rutile (R), the mid-tone gray phase corresponds to hollandite $(\mathrm{H})$ and is characterized by its large aspect ratio, and the brightest color phase corresponds to Ca-Zr-Ti-O (C). WDS elemental mapping images for selected elements are shown in Figure 6. The elemental maps show distinct partitioning of hollandite specific elements $(\mathrm{Ba}, \mathrm{Cr}$, and $\mathrm{Cs})$ and a $\mathrm{Ti}$ rich phase that was presumably $\mathrm{TiO}_{2}$. A distinct feature observed in the hollandite phase was a compositional gradient of $\mathrm{Cr}$ and $\mathrm{Fe}$ across the grains, as seen by comparing $\mathrm{Cr}$ and Fe elemental maps in Figure 6. This phenomenon was observed in samples heat treated at 1325 and $1285^{\circ} \mathrm{C}$ as well and is believed to be indicative of a fractional crystallization process as will be discussed later. Preferential partitioning of $\mathrm{Nd}, \mathrm{Zr}, \mathrm{Ca}$, and $\mathrm{Zr}$ to the bright $\mathrm{Ca}-\mathrm{Zr}-\mathrm{Ti}-\mathrm{O}$ phase was also observed in Figure 6. 
The corresponding diffraction peaks in Figure 5a, as mentioned earlier, match with multiple structures such as cubic $\mathrm{ZrO}_{2}, \mathrm{ZrTiO}_{4}$, zirconolite, and others in the $\mathrm{CaO}-\mathrm{ZrO}_{2}-\mathrm{TiO}_{2}$ system that can host any of the observed elements in their respective lattices.

Figure 7 summarizes the XRD and SEM results for the samples heat treated at $1325^{\circ} \mathrm{C}$ for $1 \mathrm{~h}, 12 \mathrm{~h}$ and $24 \mathrm{~h}$. Figure 7a shows the quantitative Rietveld refinement results based on the following phases: $\mathrm{TiO}_{2}$ (PDF: 04-006-3570), hollandite (PDF: 04-013-6380), tazheranite (PDF: 04-008-0260), perovskite (PDF: 04-014-7761), and zirconolite (PDF: 04-002-4312). The same phases (hollandite, rutile, and $\mathrm{Ca}-\mathrm{Zr}-\mathrm{Ti}-\mathrm{O}$ ) observed in the sample quenched directly from $1500^{\circ} \mathrm{C}$ were also observed in the sample annealed at $1325^{\circ} \mathrm{C}$. In addition, a perovskite and a Zr-rich phase, separate from the Ca-Zr-Ti-O phase, were identified. The perovskite phase was found in all samples, whereas the Zr-rich phase, in samples annealed for long times (12 h and 24 h), as evidenced by the best fit to the experimental pattern when both tazheranite and zirconolite were assumed to be in the system. This suggests zirconolite is the Zr-rich phase evolving from Ca-Zr-Ti-O. However, the particular chemistry of these phases remains unknown.

BSE contrast images presented in Figure $7 \mathrm{~b}$ support the XRD results and show at least 4 distinct phases in the sample annealed for $24 \mathrm{~h}$. WDS mapping images of selected elements in this sample are shown in Figure 8. The mid-tone gray phase in Figure $7 \mathrm{~b}$ was identified as hollandite $(\mathrm{H})$ and was found to have the target chemistry (Ba, $\mathrm{Cr}, \mathrm{Fe}, \mathrm{Ti}$ and $\mathrm{Cs}$ ) based on Figure 8. Importantly, Cs remained incorporated within the hollandite phase after annealing for $24 \mathrm{~h}$, indicating thermal stability of the hollandite phase with respect to Cs retention. Rutile (R) is indicated as the darkest gray phase in Figure 7b. Two distinct phases, apart from hollandite and $\mathrm{TiO}_{2}$, could also be observed in the BSE image of the sample corresponding to $t_{\mathrm{eq}}=24 \mathrm{~h}$. WDS maps show that both these regions exhibited uniform Ti distribution, as would be expected 
in both perovskite and zirconolite structures. $\mathrm{Ca}$ is present in both phases, but more concentrated in the brightest phase, which is also consistent with perovskite and zirconolite structures. This is further supported by the elemental map showing Nd-rich areas in the brightest phase. The light gray phase is rich in $\mathrm{Zr}$ and $\mathrm{Ca}$, which is consistent with a zirconolite phase.

The XRD and SEM results indicate that perovskite and Zr-rich phases crystallize at lower temperatures than the primary hollandite phase. This is further supporting evidence for the coexistence of crystalline phases with a melt in this system, in agreement with viscosity and DSC data. A chart showing the percentage of each phase as a function of annealing time is shown in Figure 9. Significant differences in phase abundance were measured in samples annealed for $1 \mathrm{~h}$ compared to $12 \mathrm{~h}$ or $24 \mathrm{~h}$ indicating that at $1325^{\circ} \mathrm{C}$, the kinetics of phase evolution and development was relatively slow by the order of hours.

Figure 10 summarizes the $\mathrm{XRD}$ and $\mathrm{SEM}$ results for the samples heat treated at $1285^{\circ} \mathrm{C}$ for $1 \mathrm{~h}, 12 \mathrm{~h}$ and $24 \mathrm{~h}$. Figure 11 shows the elemental distribution in the sample treated for $24 \mathrm{~h}$ at $1285^{\circ} \mathrm{C}$. Figure $10 \mathrm{a}$ compares the measured $\mathrm{XRD}$ patterns to calculated patterns using Rietveld quantitative phase analyses based on the following phases: $\mathrm{TiO}_{2}$ (PDF: 04-006-3570), hollandite (PDF: 04-013-6380), tazheranite (PDF: 04-008-0260), perovskite (PDF: 04-0147761), and zirconolite (PDF: 04-002-4312). XRD phase analysis and BSE images (Figures 10a and $10 \mathrm{~b}$ ) of different samples, annealed at $1285^{\circ} \mathrm{C}$ for different holding times and quenched, show similar phase assemblage and evolution as observed at $1325^{\circ} \mathrm{C}$. Perovskite and $\mathrm{Zr}$-rich phase were present in all samples that were annealed for varying times. The Zr-rich phase that was observed in the sample treated at $1325^{\circ} \mathrm{C}$ for longer times was seen at $1285^{\circ} \mathrm{C}$ even after $1 \mathrm{~h}$. Figure 12 shows a chart of the percentage of each phase as a function of annealing time. Significant differences in phase abundance were measured in samples annealed for $1 \mathrm{~h}$ compared 
to $12 \mathrm{~h}$ or $24 \mathrm{~h}$, indicating that at $1285^{\circ} \mathrm{C}$, the kinetics of phase evolution and development was relatively slow as well.

Greater understanding of the crystallization behavior of melt processed synroc-based ceramics can be made by comparing the phase and microstructural analysis of samples heat treated at 1285,1325 , and $1500^{\circ} \mathrm{C}$. With respect to phase evolution, the kinetics was time dependent at both temperatures but the type was not. For samples heat-treated at $1325^{\circ} \mathrm{C}$, the hollandite phase concentration remained relatively constant over $24 \mathrm{~h}$, whereas the perovskite and $\mathrm{Ca}-\mathrm{Zr}-\mathrm{Ti}-\mathrm{O}$ concentrations increased over time. An opposite trend was observed in samples heat treated at $1285^{\circ} \mathrm{C}$; the perovskite and $\mathrm{Ca}-\mathrm{Zr}-\mathrm{Ti}-\mathrm{O}$ concentrations remained relatively constant over 24h, whereas the hollandite concentration increased with time. In both cases, the amount of $\mathrm{TiO}_{2}$ relative to the primary phases (hollandite, perovskite, and $\mathrm{Ca}-\mathrm{Zr}-\mathrm{Ti}-\mathrm{O}$ ) was greater at shorter times $(1 \mathrm{~h})$ than longer times $(24 \mathrm{~h})$. $\mathrm{TiO}_{2}$ was the primary constituent of all the phases in the system and it followed that available $\mathrm{TiO}_{2}$ would be used up during crystal growth of all the primary phases. However, the concentration of $\mathrm{TiO}_{2}$ with time was not consistent for both temperatures. Although $\mathrm{TiO}_{2}$ concentration appeared to decrease with time for samples cooled to $1285^{\circ} \mathrm{C}$, that trend was not observed for samples cooled to $1325^{\circ} \mathrm{C}$.

Distinct compositional gradients of $\mathrm{Cr}$ and $\mathrm{Fe}$ across the phases associated with hollandite are visually apparent in the elemental maps in Figures 6, 8, and 11. High concentration of Fe along the edges of hollandite grains, accompanied by a decrease in $\mathrm{Cr}$ intensity towards the edges, can be seen. This phenomenon was more pronounced in samples quenched from lower temperatures (i.e. $1285^{\circ} \mathrm{C}>1325^{\circ} \mathrm{C}>1500^{\circ} \mathrm{C}$ ). Collectively, these results could indicate different crystal growth temperature regimes for the different phases or crystallization sequences or 
growth regimes that is dependent on other factors such as the composition of any residual melt or heterogeneous nucleation sources.

In general, the observed behavior resembles fractional crystallization such as reported during the solidification of zirconolite melts [30]. In that research, the crystallization sequence for zirconolite $\left(\mathrm{CaZrTi}_{2} \mathrm{O}_{7}\right)$ was reportedly Ti-bearing $\mathrm{ZrO}_{2} \rightarrow \mathrm{ZrTiO}_{4} \rightarrow \mathrm{Zr}$-rich $\mathrm{CaZrTi}_{2} \mathrm{O}_{7} \rightarrow$ Zr-poor $\mathrm{CaZrTi}_{2} \mathrm{O}_{7}$. The phases formed early at higher temperatures reportedly reacted with the residual melt to produce $\mathrm{Zr}$ - and Ti- rich phases surrounding each previously formed phase. The composition of the phases was correlated to the enrichment or depletion of $\mathrm{Zr}$ and $\mathrm{Ti}$ in the residual liquid phase expressed by peritectic/eutectic points in a pseudo-binary system [30]. Further explanation of the phase evolution behavior in the CAF-MP system is presented in section 3.4 .

\subsection{High-Temperature X-Ray Diffraction}

Figures 13 and 14 show in-situ XRD patterns collected during heating and cooling of CAF-MP, respectively. A baseline diffraction pattern was taken at $25^{\circ} \mathrm{C}$, before the start of the heating cycle, to confirm the phase composition of the starting material. As shown in Figure 13, the primary starting materials, (e.g. $\mathrm{TiO}_{2}, \mathrm{BaCO}_{3}, \mathrm{ZrO}_{2}, \mathrm{Cs}_{2} \mathrm{O}_{3}$, etc.) were identified. Initial indications of reaction were observed in the $800^{\circ} \mathrm{C}$ XRD pattern, which could first be identified in the $900^{\circ} \mathrm{C} \mathrm{XRD} \mathrm{patterns} \mathrm{matching} \mathrm{with} \mathrm{hollandite} \mathrm{and} \mathrm{perovskite} \mathrm{phases.} \mathrm{The} \mathrm{peak} \mathrm{intensities}$ associated with hollandite and perovskite phases were observed to grow with increasing temperature, accompanied by decreasing peak intensities of phases identified in the baseline pattern, indicating a solid-state reaction process. Initially, presence of a liquid (i.e., amorphous) phase was observed in the $1400^{\circ} \mathrm{C}$ XRD pattern as evidenced by an amorphous hump between $40-60^{\circ} 2 \theta$ and a decrease in the peak intensities of the perovskite phase from lower 
temperatures. At $1500^{\circ} \mathrm{C}$, the XRD patterns indicated an amorphous phase in combination with the hollandite phase and no indication of secondary crystalline phases. The XRD scans from $700^{\circ} \mathrm{C}$ to $1500^{\circ} \mathrm{C}$ confirm the initial reaction of the pre-cursor powders, the subsequent formation and in-growth of crystalline phases (i.e., hollandite and perovskite), and eventual partial melting of the system by dissolution of the all crystalline phases except the hollandite phase, which remains in combination with a liquid phase at temperatures up to at least $1500^{\circ} \mathrm{C}$, the highest temperature studied.

The XRD pattern at $1500^{\circ} \mathrm{C}$ in Figure 13 is the baseline pattern for the subsequent cooling cycle. That pattern is reproduced again in Figure 14, in which hollandite and an amorphous (melt) phase are evident. Upon cooling, hollandite in-grew and remained the only crystalline phase as evidenced by the $1500-1400^{\circ} \mathrm{C}$ XRD patterns. Peaks identified as belonging to perovskite and $\mathrm{Ca}-\mathrm{Zr}$-Ti-O phases appeared in the $1350^{\circ} \mathrm{C}$ XRD pattern. No measureable amorphous phase was identified in the $1350^{\circ} \mathrm{C}$ XRD pattern indicating the crystalline phases that appeared at $1350^{\circ} \mathrm{C}$ precipitated from the liquid. A set of minor peaks was observed in the XRD patterns at temperatures less than $1350^{\circ} \mathrm{C}$, which were attributed to $\mathrm{TiO}_{2}$. This result indicates that $\mathrm{TiO}_{2}$ identified in fully cooled samples precipitated upon cooling, which is known to exist in zirconolite systems [27]. Taken together, the HTXRD scans from $1500^{\circ} \mathrm{C}$ to $1100^{\circ} \mathrm{C}$ confirm that at $1500^{\circ} \mathrm{C}$ the system consisted of a partial melt with a hollandite phase, and that upon cooling, hollandite continued to in-grow followed by the eventual formation of perovskite and $\mathrm{Ca}-\mathrm{Zr}-\mathrm{Ti}-\mathrm{O}$ phases, accompanied by disappearance of the liquid phase at $\sim 1350^{\circ} \mathrm{C}$. Minor amounts of $\mathrm{TiO}_{2}$ precipitated at $\sim 1300^{\circ} \mathrm{C}$ and further cooling did not result in significant phase evolution observable to the XRD patterns, indicating complete crystallization. 
Phase evolution behavior identified from HTXRD further supports our understanding of the trend of relative phase amounts showed in Figures 9 and 12 . At $1325^{\circ} \mathrm{C}$ after $1 \mathrm{~h}$, the sample quenched was crystallized to be predominantly hollandite and the other phases being perovskite, $\mathrm{Ca}-\mathrm{Zr}-\mathrm{Ti}-\mathrm{O}$ and $\mathrm{TiO}_{2}$. The relatively high amount of $\mathrm{TiO}_{2}$ observed in the sample quenched from $1285^{\circ} \mathrm{C}$ after $1 \mathrm{~h}$ (compared to $1325^{\circ} \mathrm{C}$ after $1 \mathrm{~h}$ ) can be attributed to the precipitation of $\mathrm{TiO}_{2}$ at lower temperatures of $\sim 1300^{\circ} \mathrm{C}$. Upon annealing, the system progressed towards equilibrium resulting in relative growth or reduction of different phases as discussed in Section 3.3.

\subsection{Conclusions}

It has been demonstrated that the multiphase ceramic system is not a homogeneous melt at $1500^{\circ} \mathrm{C}$ but instead consists of nominally stoichiometric hollandite with a melt comprised of the remaining constituents. As the material is cooled, a Zr-rich phase that evolves into zirconolite and a mixed Ca-lanthanide series perovskite phase begin to form. $\mathrm{TiO}_{2}$ is also observed to ingrow upon further cooling. XRD and microstructural analysis of quenched samples suggest that the identified DSC peaks correspond to crystallization of perovskite $\left(\sim 1325^{\circ} \mathrm{C}\right)$ and zirconolite $\left(\sim 1285^{\circ} \mathrm{C}\right)$. Both zirconolite and perovskite phases are observed in samples quenched from either 1285 and $1325^{\circ} \mathrm{C}$ after holding for $>12 \mathrm{~h}$. However, zirconolite is not observed in the sample quenched from $1325^{\circ} \mathrm{C}$ after $1 \mathrm{~h}$, suggesting perovskite precedes zirconolite crystallization upon cooling. In summary, the data indicates the order of phase evolution upon cooling in this system is hollandite $\rightarrow$ perovskite $\rightarrow$ zirconolite $\rightarrow \mathrm{TiO}_{2}$. A wide range of substitutions is possible and expected in both phases and was observed in the WDS maps. Parasitic phases incorporating other elements have not been identified. An observed partitioning of $\mathrm{Cr}$ and Fe species within the hollandite phase has to be further examined. 


\section{Acknowledgements}

This document was prepared in conjunction with work accomplished under Contract\# DE-AC0908SR22470 with the U.S. Department of Energy. The authors acknowledge gratefully the financial support of the DOE-NE Materials Recovery and Waste Form Development program including program support from James Bresee, Kimberly Gray, Terry Todd and John Vienna. The authors acknowledge the financial support from the Department of Energy (DOE), Nuclear Energy University Program (NEUP). Acknowledgements are also due to Dr. Mirela Dragan for help in DSC, Gerry Wynick for WDS, and Swavek Zdzieszynski for HTXRD work. SKS acknowledges support from the Kyocera Corporation in the form of Inamori Professorship. 


\section{References}

[1] D. Caurant, P. Loiseau, O. Majerus, V. Aubin-Chevaldonnet, I. Bardez, A. Quintas, Glasses, glass-ceramics and ceramics for immobilization of highly radioactive nuclear wastes. Nova Science Publishers, New York, 2009.

[2] S.V. Stefanovsky, S.V. Yudintsev, R. Gieré, G.R. Lumpkin, Geological Society, London, Special Publications 236 (2004) 37-63.

[3] R.C. Ewing, Can. Mineral. 39 (2001) 697-715.

[4] J.-M. Montel, C. R. Geosci. 343 (2011) 230-236.

[5] A. Ringwood, S. Kesson, N. Ware, W. Hibberson, A. Major, Geochem. J. 13 (1979) 141165.

[6] A.E. Ringwood, S.E. Kesson, N.G. Ware, W. Hibberson, A. Major, Nature 278 (1979) 219-223.

[7] S.E. Kesson, T.J. White, P. Roy. Soc. Lond. A. Mat. 405 (1986) 73-101.

[8] R.W. Cheary, J. Kwiatkowska, J. Nucl. Mater. 125 (1984) 236-243.

[9] R.W. Cheary, Mater. Sci. Forum. 27 (1988) 397-406.

[10] S.E. Kesson, T.J. White, P. Roy. Soc. Lond. A. Mat. 408 (1986) 295-319.

[11] M. Pena, J. Fierro, Chem. Rev. 101(7) (2001) 1981-2018.

[12] G.R. Lumpkin, Elements 2(6) (2006) 365-372.

[13] V. Aubin-Chevaldonnet, D. Caurant, A. Dannoux, D. Gourier, T. Charpentier, L. Mazerolles, T. Advocat, J. Nucl. Mater. 366 (2007) 137-160.

[14] Y. Zhang, H. Li, S. Moricca, J. Nucl. Mater. 377 (2008) 470-475.

[15] S. Stefanovsky, A. Ptashkin, O. Knyazev, S. Dmitriev, S. Yudintsev, B. Nikonov, J. Alloy Compd. 444 (2007) 438-442.

[16] B. Clark, P. Tumurugoti, S. Sundaram, J. Amoroso, J. Marra, K. Brinkman, Metall. Mater. Trans. E 1(4) (2014) 341-348.

[17] P. Tumurugoti, S. Sundaram, K. Brinkman, J. Amoroso, K. Fox, Ceram. Trans. 250 (2014) 205-212.

[18] J. Amoroso, J.C. Marra, M. Tang, Y. Lin, F. Chen, D. Su, K.S. Brinkman, J. Nucl. Mater. 454 (2014) 12-21.

[19] J. Amoroso, J. Marra, S.D. Conradson, M. Tang, K. Brinkman, J. Alloy Compd. 584 (2014) 590-599. 
[20] K. M. Fox, ITS-0058, SRNL L29 Manual, Savannah River National Laboratory, Aiken, SC, 2010.

[21] R.F. Schumacher, R.J. Workman, T.B. Edwards, WSRC-RP-2000-00874, Savannah River National Laboratory, Aiken, SC, 2001.

[22] R.F. Schumacher, R.J. Workman, T.B. Edwards, WSRC-RP-98-00737, Savannah River National Laboratory, Aiken, SC, 1998.

[23] J.E. Shelby, Introduction to glass science and technology, Royal Society of Chemistry, Cambridge, UK, 2005.

[24] A. A. Kashaev, Z.F. Ushchapovskaia, Sov. Phys. Crystal. 14 (1969) 1064-1065.

[25] M. Yoshimura, Am. Ceram. Soc. Bull. 67(12) (1988) 1950-1955.

[26] P. Li, I.W. Chen, J.E. Penner-Hahn, J. Am. Ceram. Soc. 77 (1994) 1289-1295.

[27] P. Li, I.W. Chen, J.E. Penner-Hahn, J. Am. Ceram. Soc. 77 (1994) 118-128.

[28] W. Gong, W. Lutze, R. Ewing, J. Nucl. Mater. 277 (2000) 239-249.

[29] D. Swenson, T.-G. Nieh, J.H. Fournelle, J. Am. Ceram. Soc. 81(12) (1998) 3249-3252.

[30] H. Xu, Y. Wang, J. Nucl. Mater. 279 (2000) 100-106.

\section{Table Captions}

Table 1. Target composition of CAF-MP

Table 2. Temperature parameters used for quenching experiments 


\section{Figure captions}

Figure 1. Temperature-time profile used for DSC experiments. ' $\alpha$ ' is the constant heating/cooling rate used.

Figure 2. Heat cycle used for quenching experiments.

Figure 3. Viscosity as a function of temperature for CAF-MP. The accuracy of individual viscosity values is $+/-20 \%$ based on historical data for a reference material measured on the same instrument. The lines through the data are linear fits to aid the eye.

Figure 4. DSC curves showing exothermic peaks between $1280^{\circ} \mathrm{C}$ and $1330^{\circ} \mathrm{C}$. The sharp peak on the dotted line $(5 \mathrm{~K} / \mathrm{min})$ is an external fluctuation.

Figure 5. (a) Quantitative XRD analysis of CAF-MP quenched from $1500^{\circ} \mathrm{C}$ and held for $4 \mathrm{~h}$. Best fit for Rietveld pattern refinement was obtained with hollandite $(\mathrm{H}), \mathrm{TiO}_{2}(\mathrm{~T})$ and tazheranite (C) (b) Corresponding back-scattered images.

Figure 6. WDS maps of selected elements of CAF-MP at $1500^{\circ} \mathrm{C}$ annealed for $4 \mathrm{~h}$. Different phases are labelled on the BSE graphic - hollandite $(\mathrm{H})$ and $\mathrm{TiO}_{2}(\mathrm{~T})$. The brightest background phase is $\mathrm{Ca}-\mathrm{Zr}-\mathrm{Ti}-\mathrm{O}$.

Figure 7. (a) Quantitative XRD analysis of CAF-MP quenched from $1325^{\circ} \mathrm{C}$ held for varying times. Best fit for Rietveld pattern refinement was obtained with hollandite $(\mathrm{H}), \mathrm{TiO}_{2}$ (T), tazheranite (C) and zirconolite (Z) (b) Corresponding back-scattered images.

Figure 8. WDS maps of selected elements of CAF-MP at $1325^{\circ} \mathrm{C}$ annealed for $24 \mathrm{~h}$. Different phases are labelled on the BSE graphic. (Multiple sweeps were done across the selected area to collect the maps. A shift in the scanned area occurred between different sweeps, as seen in few elemental maps. No shift was observed during individual sweeps.) 
Figure 9. Quantitative phase distribution as a function of annealing time at $1325^{\circ} \mathrm{C}$. Ca-Zr-Ti-O represents both tazheranite and zirconolite phases from Rietveld refinement.

Figure 10. (a) Quantitative XRD analysis of CAF-MP quenched from $1285^{\circ} \mathrm{C}$ held for varying times. Best fit for Rietveld pattern refinement was obtained with hollandite $(\mathrm{H}), \mathrm{TiO}_{2}$ (T), tazheranite (C) and zirconolite (Z) (b) Corresponding back-scattered images.

Figure 11. WDS maps of selected elements of CAF-MP at $1285^{\circ} \mathrm{C}$ annealed for $24 \mathrm{~h}$. Multiple sweeps were done across the selected area to collect the maps. (Here also, a shift in the scanned area occurred between different sweeps, as seen in few elemental maps.)

Figure 12. Quantitative phase distribution as a function of annealing time at $1285^{\circ} \mathrm{C}$. Ca-Zr-Ti-O represents both tazheranite and zirconolite phases from Rietveld refinement.

Figure 13. In-situ XRD patterns collected at different temperatures during heating from $25^{\circ} \mathrm{C}$ to $1500^{\circ} \mathrm{C}$. Different phases in the starting material are $\mathrm{B}-\mathrm{BaCO}_{3}, \mathrm{Z}-\mathrm{ZrO}_{2}, \mathrm{~T}-\mathrm{TiO}_{2}$ (anatase), $\mathrm{Cs}-\mathrm{Cs}_{2} \mathrm{CO}_{3}, \mathrm{C}-\mathrm{CeO}_{2}$, and $\mathrm{Cr}-\mathrm{Cr}_{2} \mathrm{O}_{3}$.

Figure 14. In-situ XRD patterns collected during cooling from $1500^{\circ} \mathrm{C}$ to room temperature (RT). 
Table 1.

\begin{tabular}{c|c|c|c}
\hline & $\begin{array}{c}\text { Target wt\% of } \\
\text { each oxide in } \\
\text { CAF-MP }\end{array}$ & & $\begin{array}{c}\text { Target wt\% of } \\
\text { each oxide in } \\
\text { CAF-MP }\end{array}$ \\
\hline $\mathrm{Al}_{2} \mathrm{O}_{3}$ & 1.27 & $\mathrm{MoO}_{3}$ & 0.85 \\
$\mathrm{BaO}$ & 12.76 & $\mathrm{Nd}_{2} \mathrm{O}_{3}$ & 5.23 \\
$\mathrm{CaO}$ & 1.39 & $\mathrm{Pr}_{2} \mathrm{O}_{3}$ & 1.45 \\
$\mathrm{Cr} \mathrm{O}_{3}$ & 6.33 & $\mathrm{SeO}_{2}$ & 0.08 \\
$\mathrm{CdO}$ & 0.11 & $\mathrm{Sm}_{2} \mathrm{O}_{3}$ & 1.08 \\
$\mathrm{Ce}_{2} \mathrm{O}_{3}$ & 3.10 & $\mathrm{SnO}_{2}$ & 0.07 \\
$\mathrm{Cs}_{2} \mathrm{O}$ & 2.88 & $\mathrm{SrO}$ & 0.98 \\
$\mathrm{Eu}_{2} \mathrm{O}_{3}$ & 0.17 & $\mathrm{TeO}_{2}$ & 0.66 \\
$\mathrm{Fe}_{2} \mathrm{O}_{3}$ & 6.65 & $\mathrm{TiO}_{2}$ & 49.16 \\
$\mathrm{Gd}_{2} \mathrm{O}_{3}$ & 0.16 & $\mathrm{Y}_{2} \mathrm{O}_{3}$ & 0.63 \\
$\mathrm{La}_{2} \mathrm{O}_{3}$ & 1.58 & $\mathrm{ZrO}_{2}$ & 2.99 \\
\hline
\end{tabular}


Table 2.

\begin{tabular}{|c|c|c|c|c|}
\hline $\mathbf{T}_{\mathbf{m}}$ & ' $\boldsymbol{T}^{\prime}$ & \multicolumn{3}{|c|}{$\boldsymbol{t}_{\boldsymbol{e q}}(\mathbf{h})$} \\
\hline $1500^{\circ} \mathrm{C}$ & $1500^{\circ} \mathrm{C}$ & \multicolumn{3}{|c|}{4} \\
\hline $1500^{\circ} \mathrm{C}$ & $1325^{\circ} \mathrm{C}$ & 1 & 12 & 24 \\
\hline $1500^{\circ} \mathrm{C}$ & $1285^{\circ} \mathrm{C}$ & 1 & 12 & 24 \\
\hline
\end{tabular}


Figure's

Figure 1




Figure 2




Figure 3

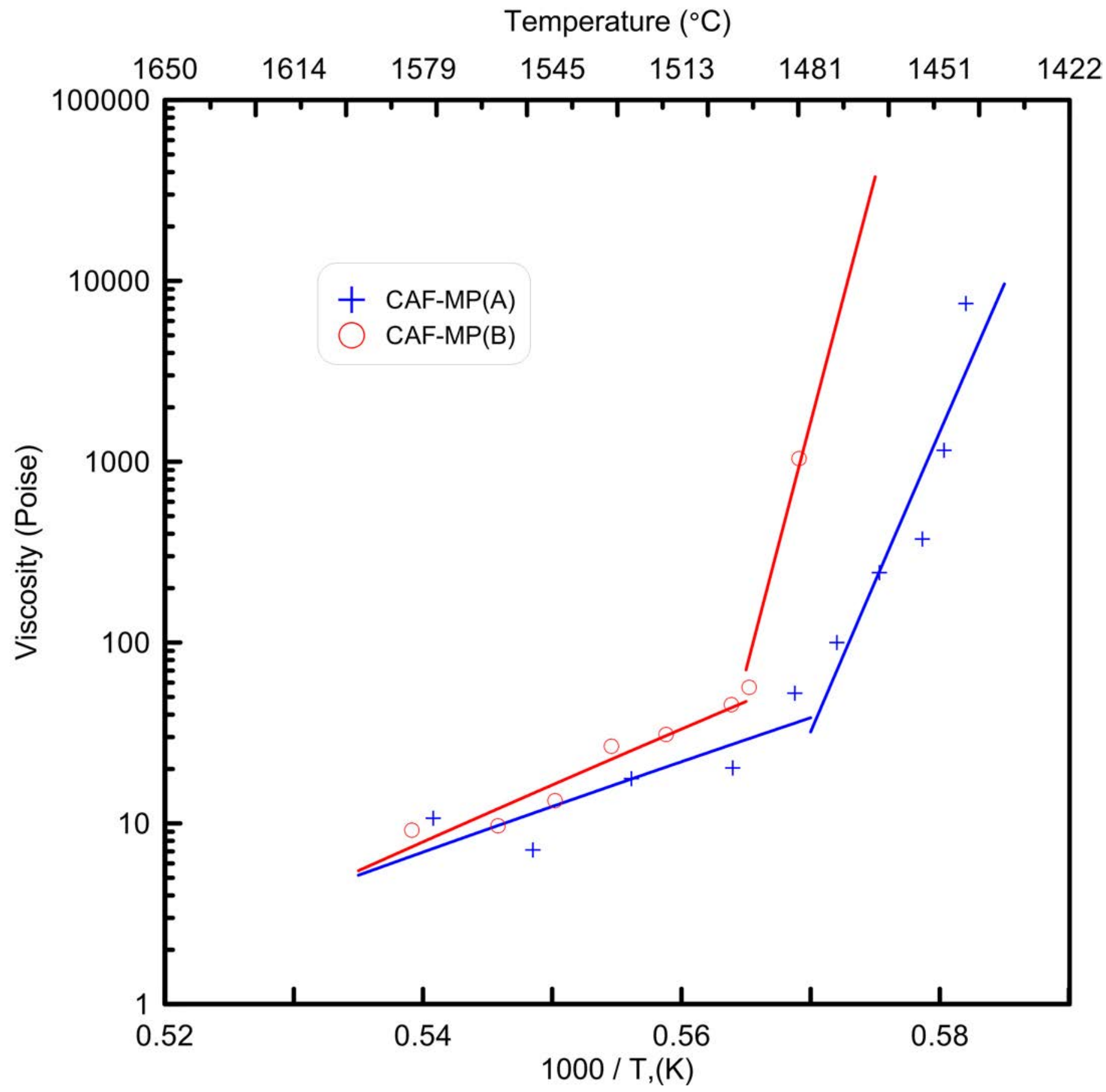


Figure 4

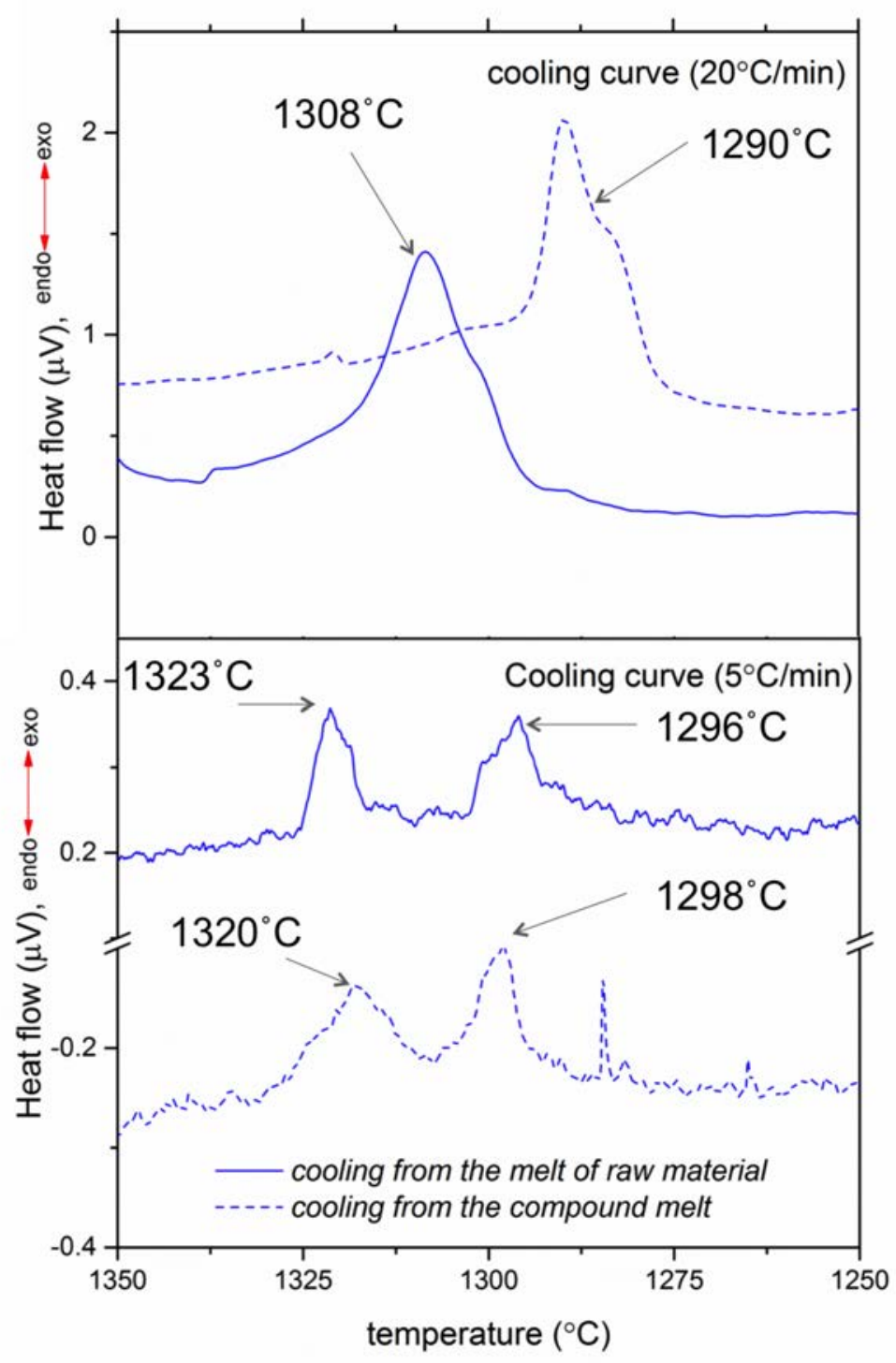


Figure 5



(a)

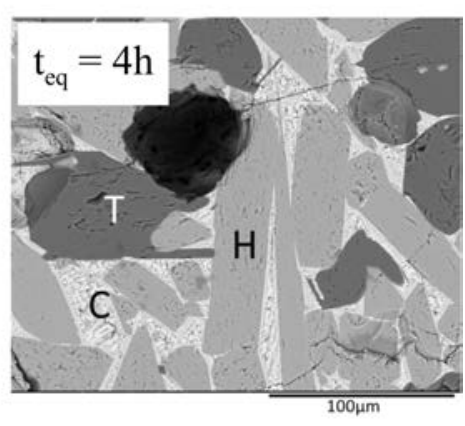

(b) 
Figure 6

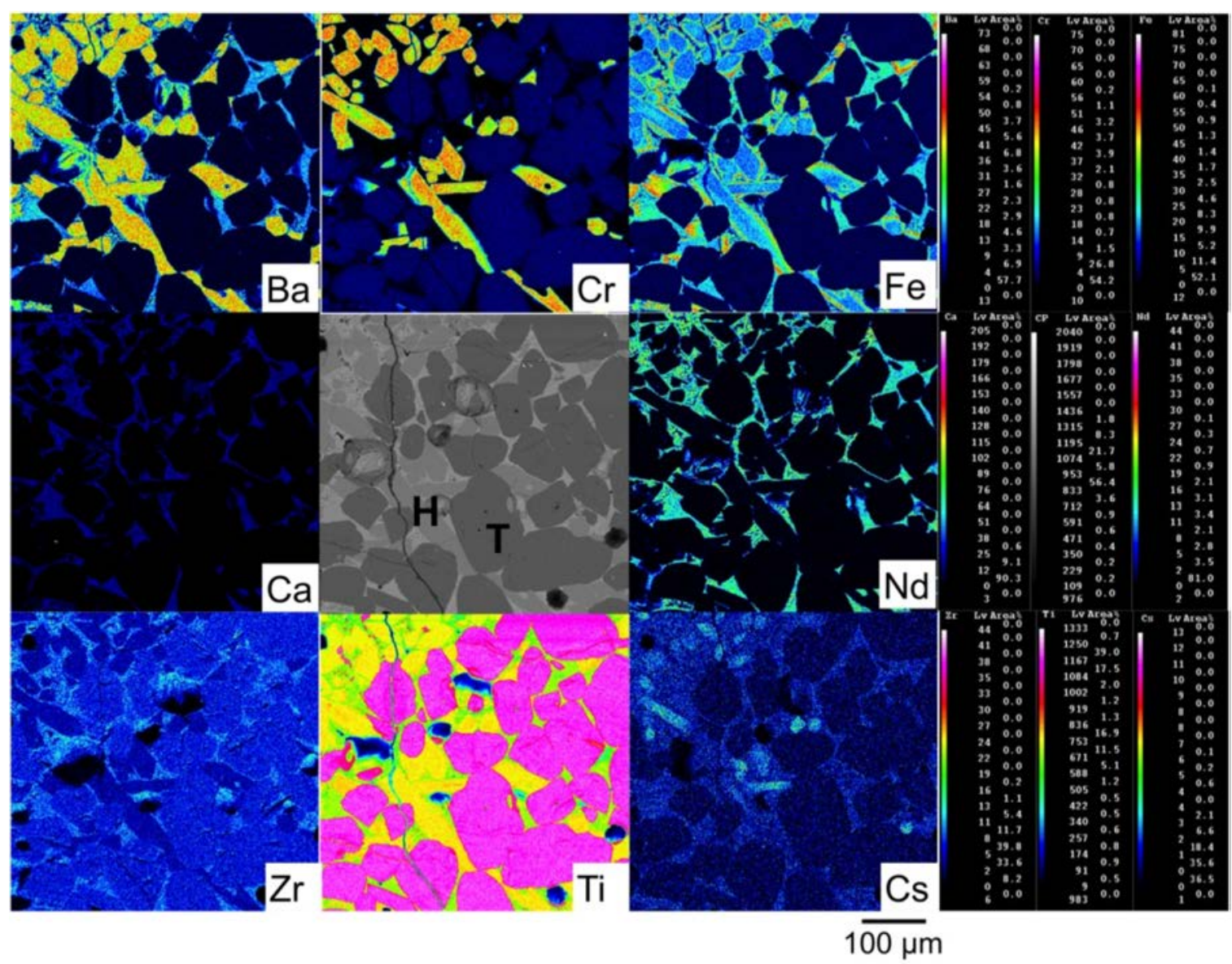


Figure 7

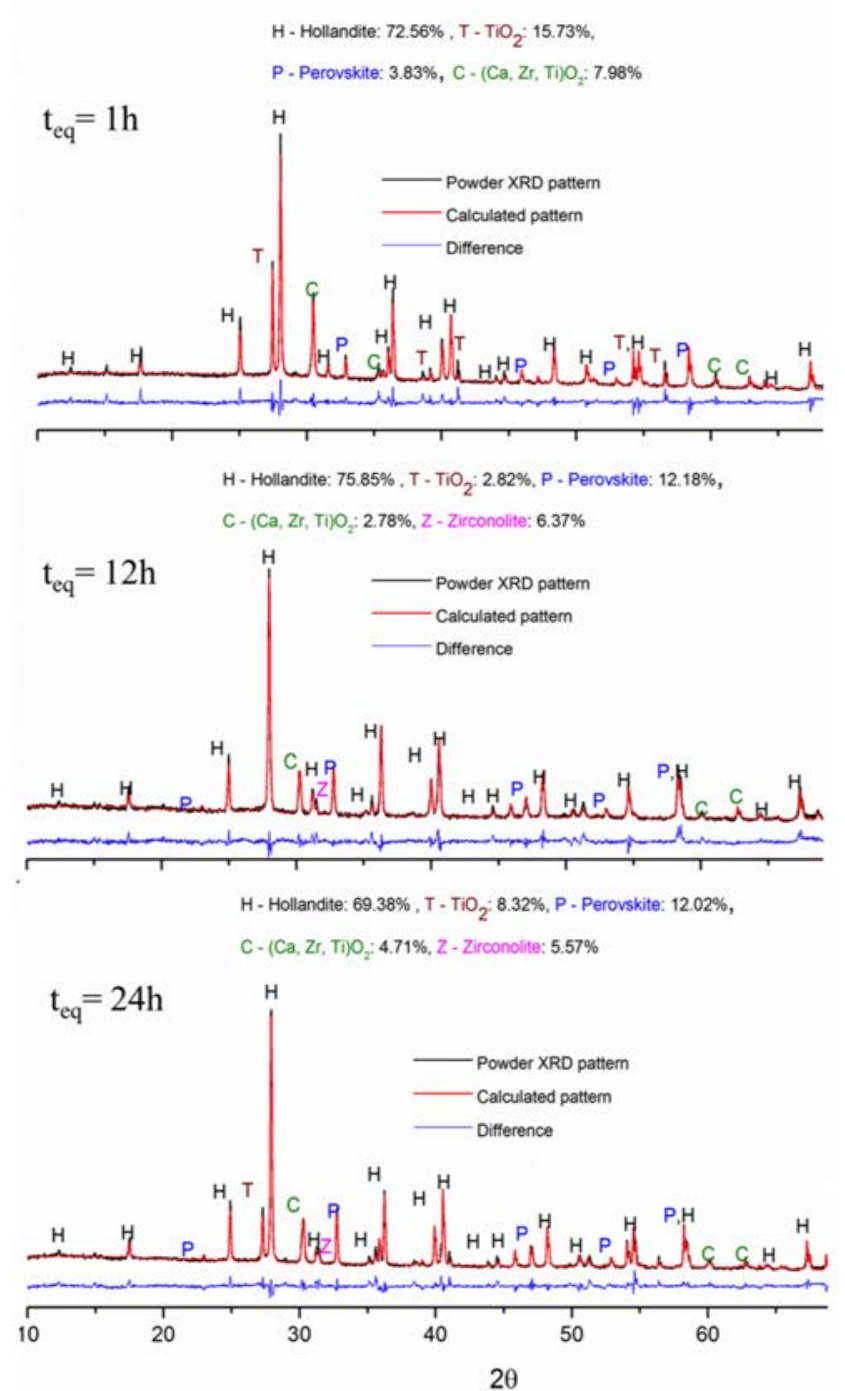

(a)

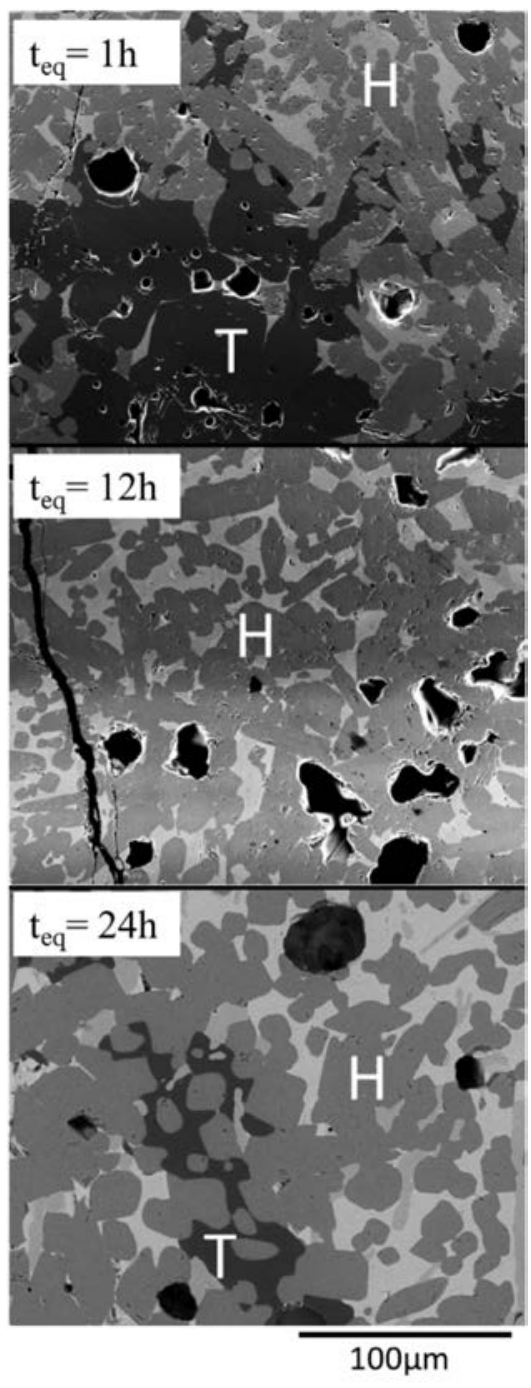

(b) 
Figure 8

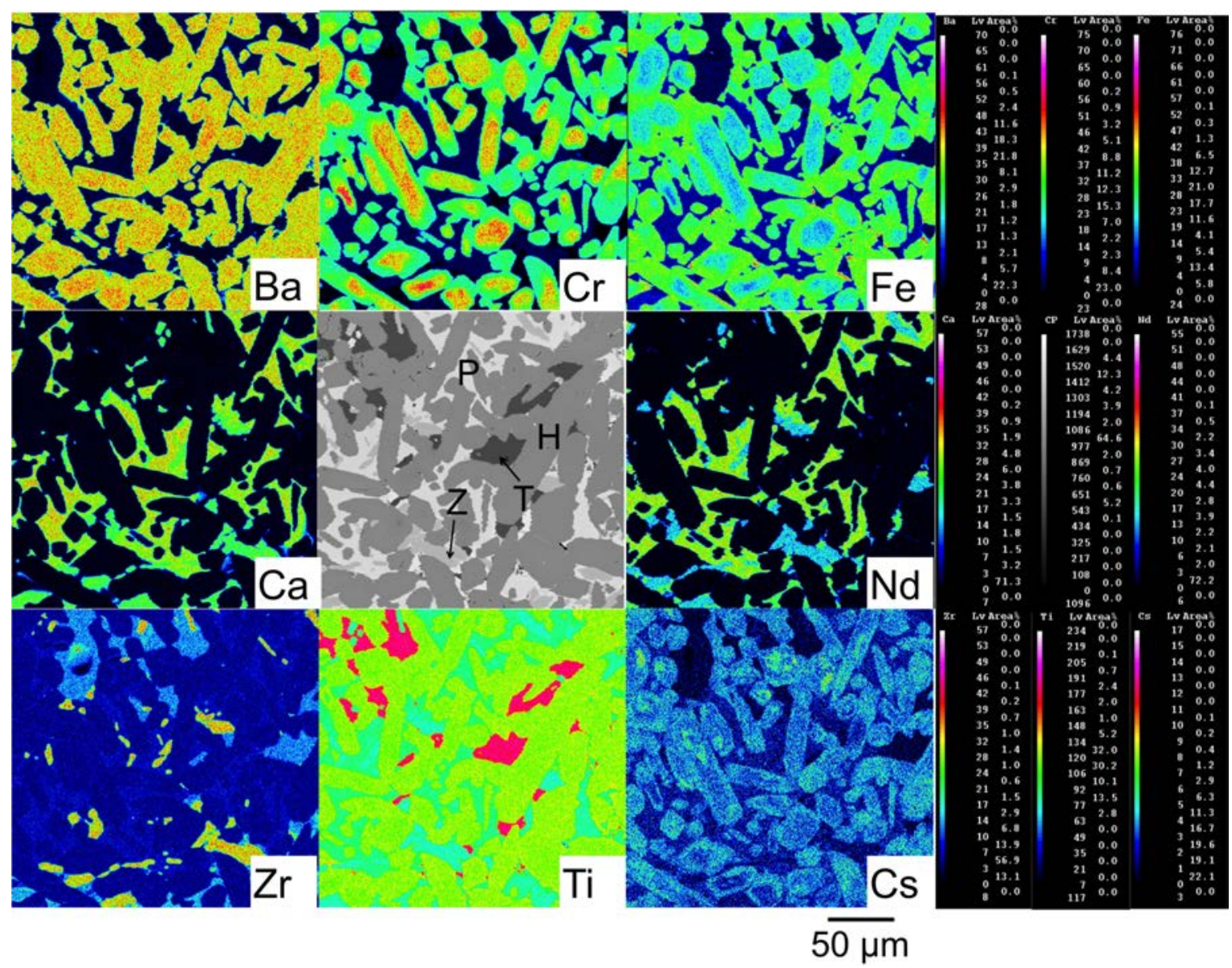


Figure 9

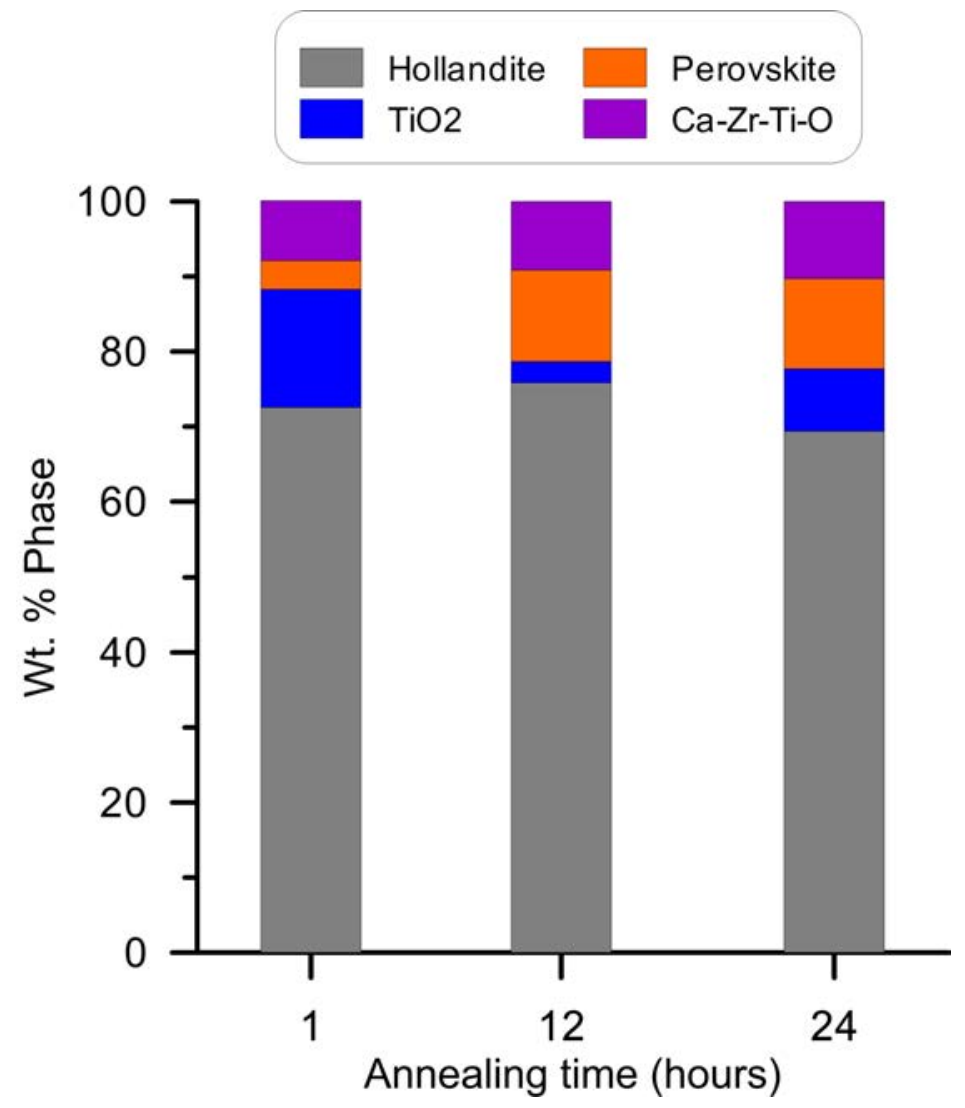


Figure 10

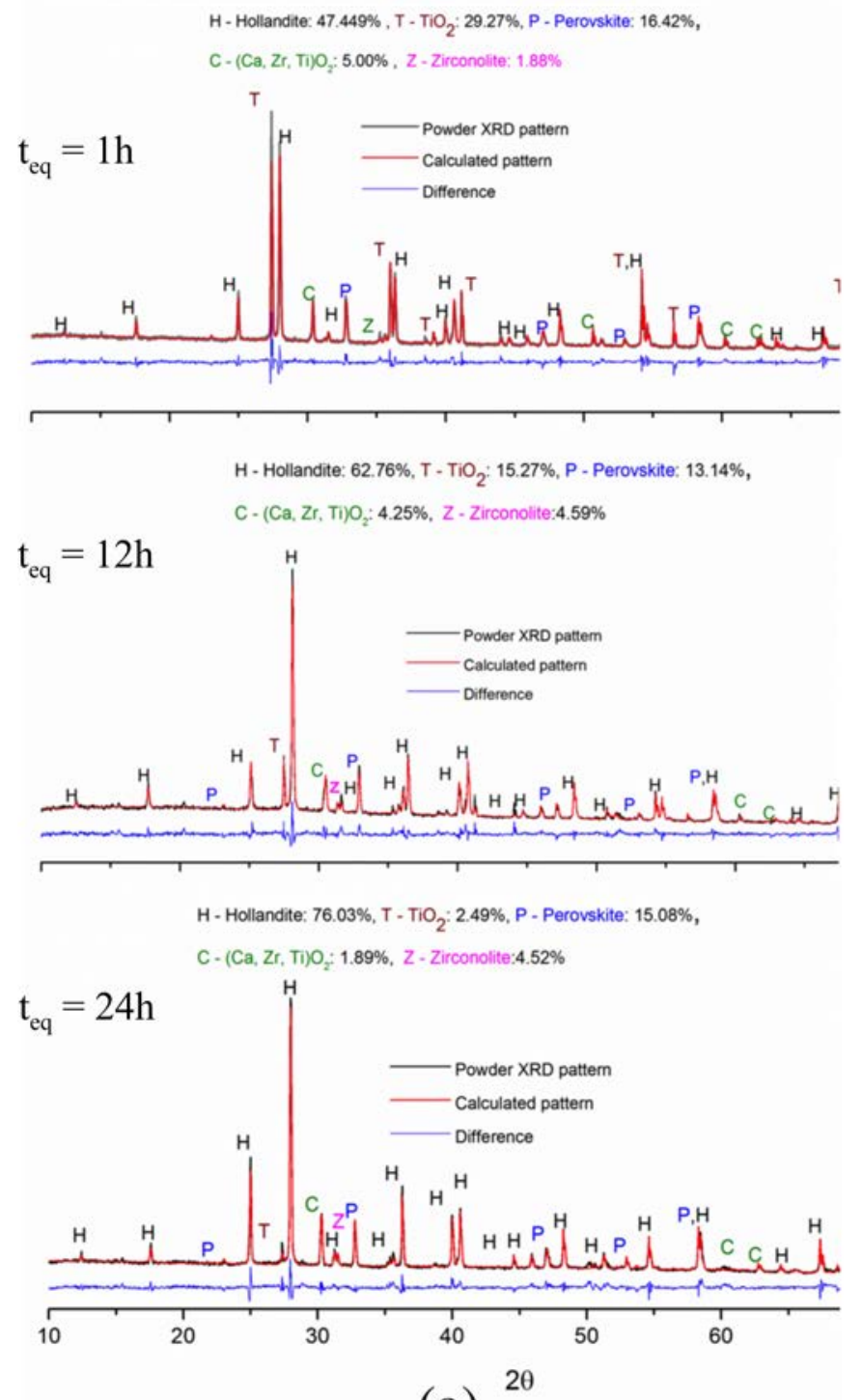

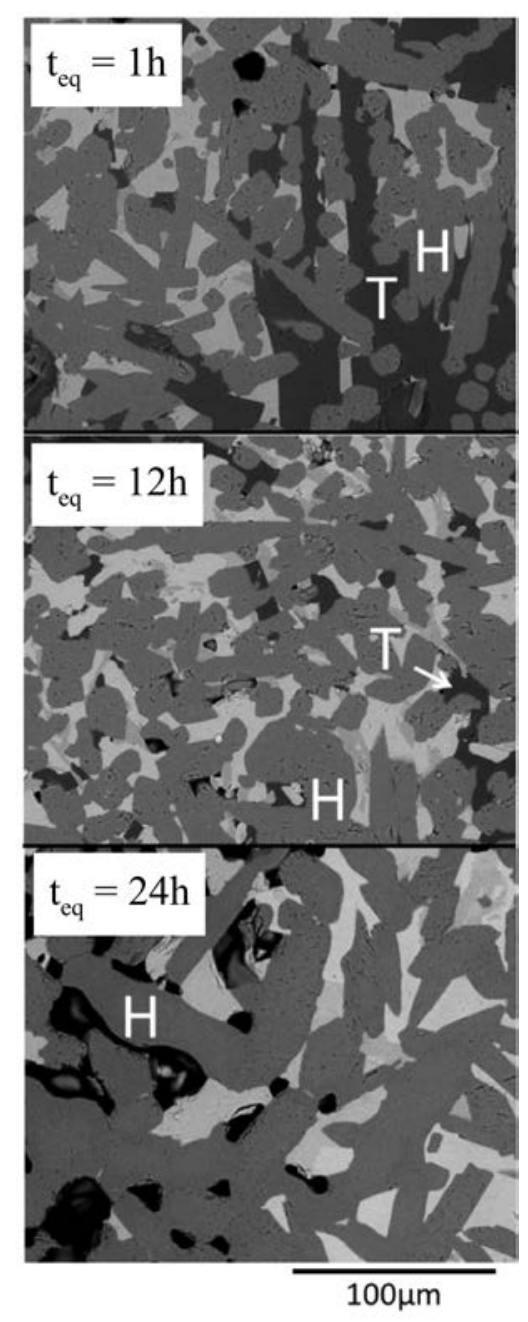

(b) 
Figure 11

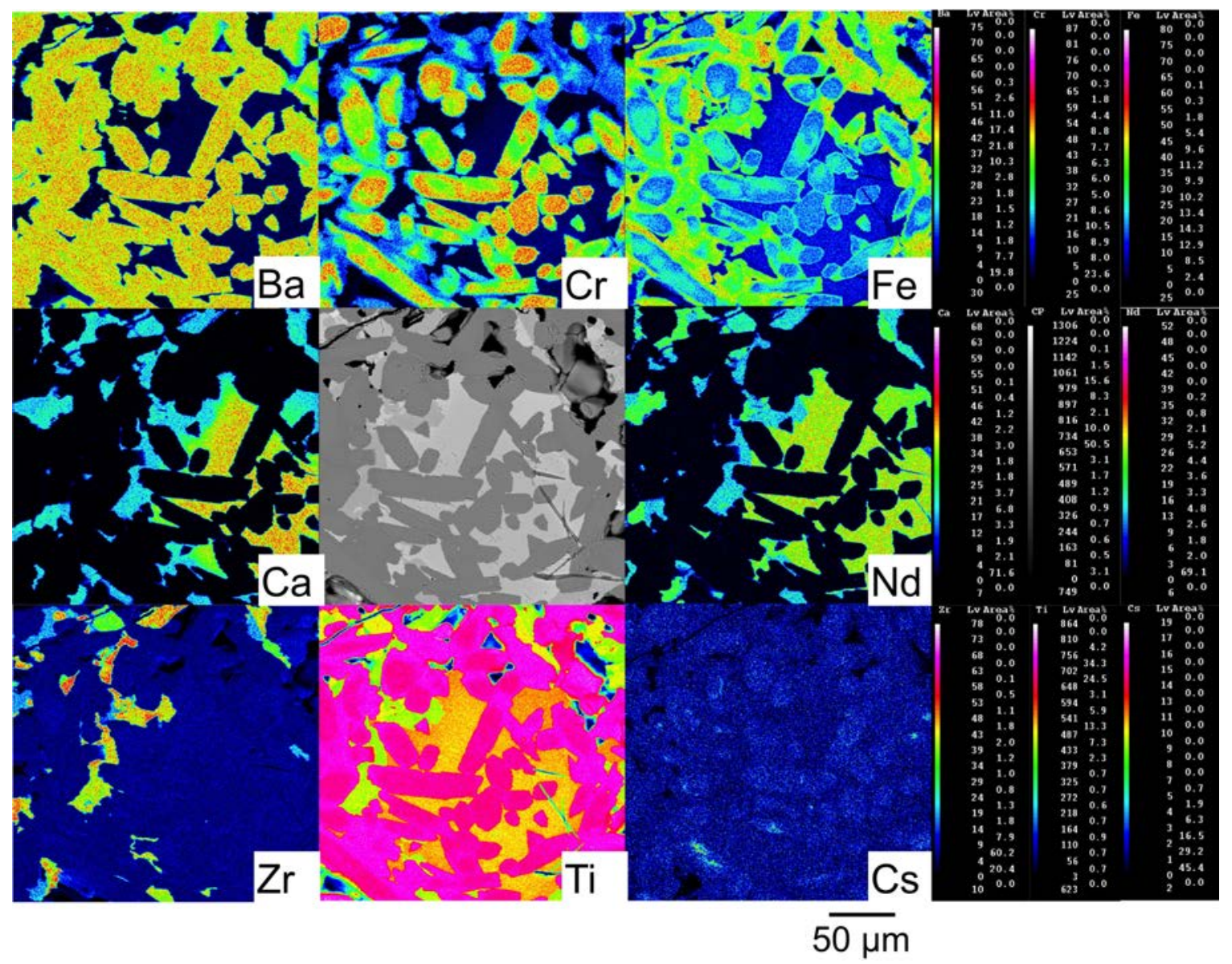


Figure 12




Figure 13

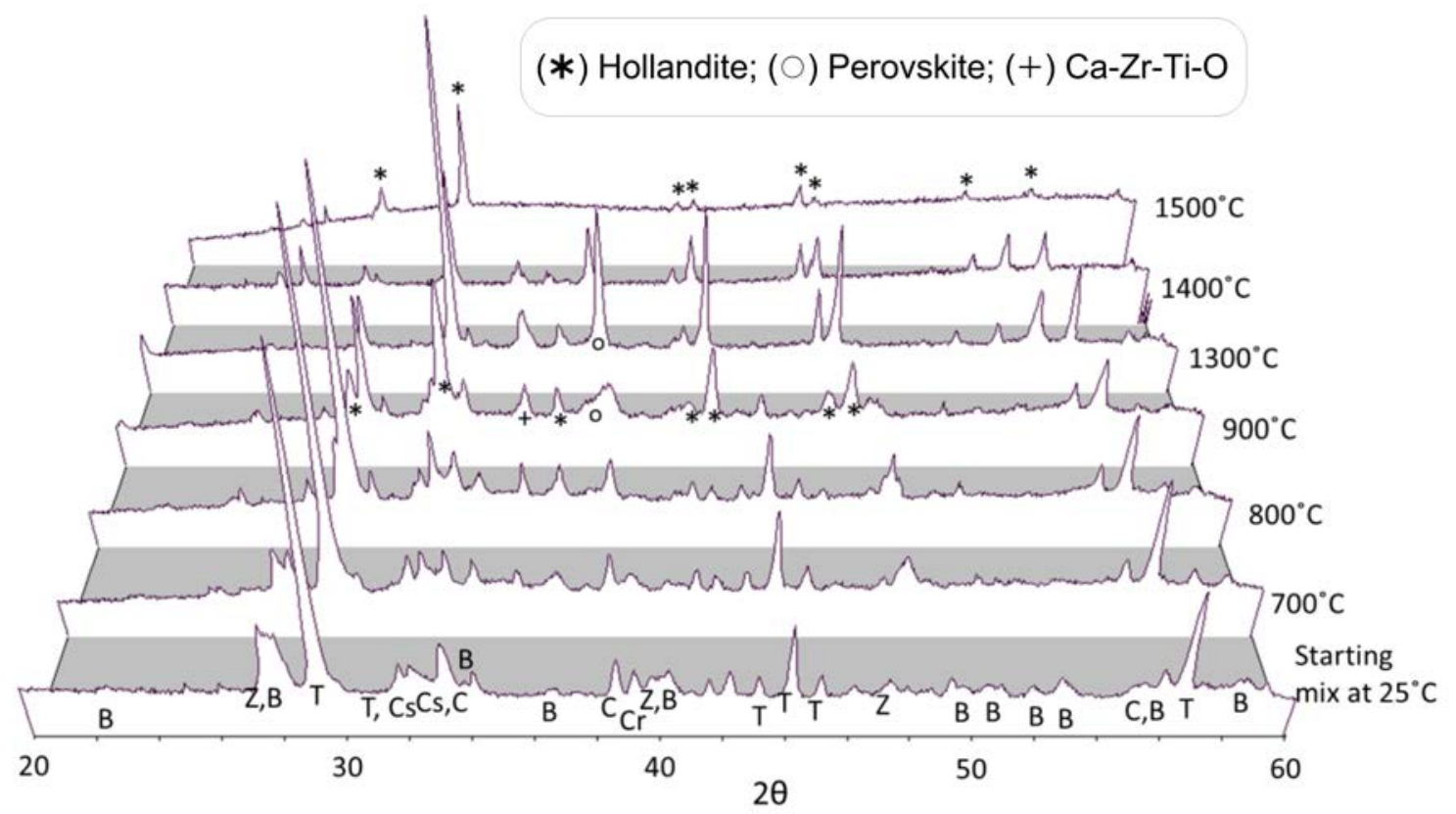


Figure 14

(*) Hollandite; (○) Perovskite; (+) Ca-Zr-Ti-O; (^) $\mathrm{TiO}_{2}$

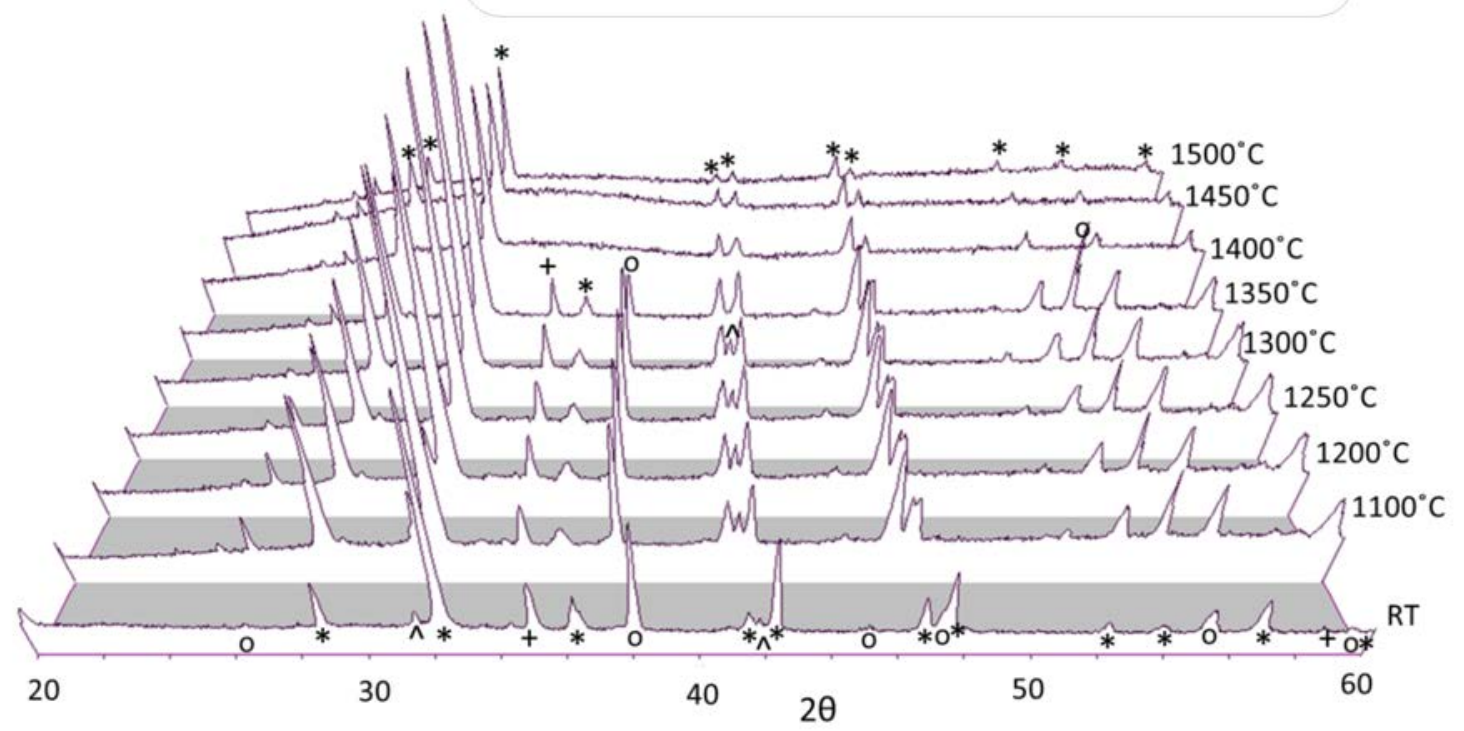

